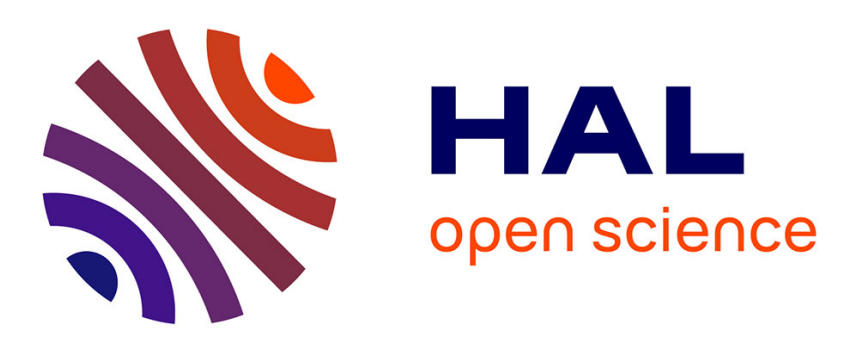

\title{
Catalytic study of SOFC electrode materials in engine exhaust gas atmosphere
}

\author{
Pauline Briault, Mathilde Rieu, Richard Laucournet, Bertrand Morel, \\ Jean-Paul Viricelle
}

\section{> To cite this version:}

Pauline Briault, Mathilde Rieu, Richard Laucournet, Bertrand Morel, Jean-Paul Viricelle. Catalytic study of SOFC electrode materials in engine exhaust gas atmosphere. Journal of Materials Science, 2013, 48 (20), pp.7184-7195. 10.1007/s10853-013-7535-y · hal-00850716

\section{HAL Id: hal-00850716 https://hal.science/hal-00850716}

Submitted on 8 Aug 2013

HAL is a multi-disciplinary open access archive for the deposit and dissemination of scientific research documents, whether they are published or not. The documents may come from teaching and research institutions in France or abroad, or from public or private research centers.
L'archive ouverte pluridisciplinaire HAL, est destinée au dépôt et à la diffusion de documents scientifiques de niveau recherche, publiés ou non, émanant des établissements d'enseignement et de recherche français ou étrangers, des laboratoires publics ou privés. 


\title{
Catalytic study of SOFC electrode materials in engine exhaust gas atmosphere
}

\author{
Pauline Briault ${ }^{\mathrm{a}}$, Mathilde Rieu ${ }^{\mathrm{a}}$,*, Richard Laucournet ${ }^{\mathrm{b}}$, Bertrand Morel $^{\mathrm{b}}$, Jean-Paul \\ Viricelle $^{\mathrm{a}}$ \\ a Ecole Nationale Supérieure des Mines, SPIN-EMSE, CNRS:UMR5307, LGF, F-42023 Saint- \\ Etienne \\ ${ }^{\mathrm{b}}$ French Alternative Energies and Atomic Energy Commission CEA-LITEN \\ 17, rue des martyrs 38054 Grenoble cedex 9 \\ * Corresponding author: M. Rieu, Tel: +33477420282, Fax: +33477499694, e-mail: rieu@emse.fr
}

\begin{abstract}
A Single Chamber Solid Oxide Fuel Cell (SC-SOFC) is a device able to produce electricity from a mixture of hydrocarbons and oxidant. An innovative application of this system would be to recover energy from exhaust gas of a thermal engine. This paper presents a study of stability and catalytic behaviour of electrode materials composing the cell in a mixture of hydrocarbons (propane, propene), oxygen, carbon monoxide, carbon dioxide, hydrogen and water corresponding to a composition of exhaust gas. A screening of four cathode materials was done, some well-known materials in literature and leading to highest performances such as $\mathrm{La}_{0.6} \mathrm{Sr}_{0.4} \mathrm{Co}_{0.2} \mathrm{Fe}_{0.8} \mathrm{O}_{3-\delta}\left(\mathrm{LSCF}_{)}, \mathrm{Sm}_{0.5} \mathrm{Sr}_{0.5} \mathrm{CoO}_{3-\delta}\right.$ (SSC) and $\mathrm{Ba}_{0.5} \mathrm{Sr}_{0.5} \mathrm{Co}_{0.8} \mathrm{Fe}_{0.2} \mathrm{O}_{3-\delta}$ (BSCF) and a last one $\mathrm{Pr}_{2} \mathrm{NiO}_{4+\delta}$ (PNO) very promising for conventional SOFCs. Anode material was a cermet composed of nickel and $\mathrm{Ce}_{0.9} \mathrm{Gd}_{0.1} \mathrm{O}_{1.95}$ (GDC) which was also selected as the electrolyte material. Chemical stability tests and catalytic activity studies in the gas mixture were performed on the raw materials and have led to a first selection among cathodes. Two hydrocarbons/oxygen ratios $\left(\mathrm{R}=\mathrm{HC} / \mathrm{O}_{2}\right)$ were investigated for materials tests considering the gas mixture stability at high temperature $\left(600^{\circ} \mathrm{C}\right): \mathrm{R}=0.21$ and $\mathrm{R}=0.44$. LSCF and $\mathrm{PNO}$ were considered as the most stable cathode materials, besides LSCF demonstrated a lower catalytic activity towards hydrocarbon partial oxidation than PNO especially for the $\mathrm{R}=0.44$ ratio. As for the anode side, nickel was tested regarding its catalytic activity towards hydrocarbons oxidation. It exhibited catalytic activity towards hydrocarbons partial oxidation, especially for the oxygen-lean ratio (0.44), which gradually decreased while lowering temperature from $620^{\circ} \mathrm{C}$ to $450^{\circ} \mathrm{C}$.
\end{abstract}

Keywords: Single chamber SOFC, exhaust gas, catalytic activity, electrode materials 


\section{Introduction}

Solid oxide fuel cells are usually described as devices able to convert chemical energy into electrical energy. Conventional solid oxide fuel cells are separated into two compartments containing each electrode split by a gastight insulating electrolyte. Fuel (hydrogen, in most cases) and oxidant (oxygen or air) are directly supplied to each chamber and no mixing of the two gases is tolerated. At the cathode side, oxygen is reduced into oxygen ions (1) which migrate through the electrolyte to the anode side, where they oxidise hydrogen (2). Electrons produced by hydrogen oxidation are then provided to the cathode through an outer circuit. The overall reaction is the chemical oxidation of hydrogen to water (3).

$$
\begin{aligned}
& \mathrm{O}_{2}+4 \mathrm{e}^{-} \rightarrow 2 \mathrm{O}^{2-} \\
& \mathrm{H}_{2}+\mathrm{O}^{2-} \rightarrow \mathrm{H}_{2} \mathrm{O}+2 \mathrm{e}^{-} \\
& \mathrm{H}_{2}+1 / 2 \mathrm{O}_{2} \rightarrow \mathrm{H}_{2} \mathrm{O}
\end{aligned}
$$

Since the early nineties $[1,2]$, SOFC have been studied in a new configuration where anode and cathode are exposed to the same gas mixture and contained in a single chamber. Therefore, no sealing between compartments is required, removing one of the main issues of conventional SOFCs. However, in this case, hydrogen cannot be used as a fuel since hydrogen-air mixtures are highly reactive, thus hydrocarbons, able to form hydrogen and carbon monoxide through partial oxidation (4), are most commonly used in the gas mixture.

$$
\mathrm{C}_{\mathrm{n}} \mathrm{H}_{\mathrm{m}}+\mathrm{n} / 2 \mathrm{O}_{2} \rightarrow \mathrm{n} \mathrm{CO}+\mathrm{m} / 2 \mathrm{H}_{2}
$$

Since there is no difference in the gas mixture at each sides of the cell, single chamber operation principle is based on the difference of electrodes catalytic activity towards hydrocarbons oxidation. Electrode materials have to fulfil some requirements. Anode cermet must be fully active for hydrocarbons oxidation into hydrogen and carbon monoxide and for electrochemical oxidation of the hydrogen as well. On the contrary, cathode material has to be inert to hydrocarbons oxidation, but active for oxygen reduction reaction and chemically stable in a slightly reducing atmosphere. When no current is drawn, the depletion of oxygen at the anode and the maximum concentration of oxygen at the cathode cause an oxygen partial pressure gradient between both sides of the cell leading to an open circuit voltage (OCV). The single chamber configuration has several advantages over conventional SOFCs: new cell geometries, stack assembly and miniaturization of cells [3] are more easily conceivable. These advantages open the way to new applications such as energy recovery in exhaust gas and hazardous emission reduction. For this process, partly developed in the present article, cells are embedded at the exit of an engine and turn unburned hydrocarbons from exhaust gas into electricity, which could then feed electronic devices in vehicles. This forward-looking energy recovery device could be also used in thermal stationary power plants as well, in order to reduce hydrocarbons emissions and increase energy efficiency. 
To date, only a few authors have studied this system. Herman et al. from Hewlett Packard group [4] and Uchiyama et al. [5] in their patents of 2004 and 2007, developed equivalent devices. Naoki Uchiyama collaborated on testing such a system in real conditions with Takashi Hibino's group; two articles dealing with the results were published in 2008 [6,7]. Concerning the gas mixture used for tests, the articles and patents have exposed only evasive or simplified compositions. Herman's patent [4], described a mixture composed of light hydrocarbons (e.g. methane, ethane...), hydrogen and oxygen with no exact composition. As for Uchiyama [5], hydrocarbons, carbon oxides and air are the components of the studied atmosphere, without any further details. Hibino's group is the only one who detailed the complete composition of its studied stream for single cell test [6,7]. A mixture of four hydrocarbons (methane, ethane, propane and butane), supplied at a concentration of $1000 \mathrm{ppm}$ for each species, and oxygen ranging from 1250 to 15000 ppm is described. Nevertheless, no exact composition is given for the test of a stack implemented within a scooter exhaust line.

In this kind of gas mixture, electrodes selectivity is decisive for an optimal operation of cells. Some authors had previously dealt with catalytic activity towards hydrocarbons oxidation of well-known cathode materials. Activities of $\mathrm{La}_{0.6} \mathrm{Sr}_{0.4} \mathrm{Co}_{0.2} \mathrm{Fe}_{0.8} \mathrm{O}_{3-\delta}$ (LSCF), $\mathrm{Sm}_{0.5} \mathrm{Sr}_{0.5} \mathrm{CoO}_{3-\delta}$ (SSC) and $\mathrm{Ba}_{0.5} \mathrm{Sr}_{0.5} \mathrm{Co}_{0.8} \mathrm{Fe}_{0.2} \mathrm{O}_{3-\delta}$ (BSCF) cathodes were studied by Shao et al. [8] and Viricelle et al. [9] in a $\mathrm{C}_{3} \mathrm{H}_{8} / \mathrm{O}_{2}$ mixture, and also by Rembelski et al. [10] in a $\mathrm{CH}_{4} / \mathrm{O}_{2}$ mixture. Each cathode material demonstrated a lower catalytic activity towards hydrocarbons oxidation than the widely used LSM. Moreover, BSCF exhibited in each case the lowest hydrocarbons conversion rate especially in a propane/oxygen atmosphere. By using BSCF as cathode material in single cell operation, Shao et al. [11], in 2011, reached the highest power density ever measured in single chamber conditions: $1500 \mathrm{~mW} . \mathrm{cm}^{-2}$ were delivered by an anode supported BSCF-SDC/SDC/YSZ/Ni-YSZ cell. However, even if Shao et al. [8] reported no degradation of this material in a hydrogen-oxygen mixed atmosphere, Viricelle et al. and Rembelski et al. [9,10] demonstrated that BSCF, as well as SSC, show a strong degradation by reaction with $\mathrm{CO}_{2}$ in a single chamber representative atmosphere, involving a longterm stability issue during cell operation.

As well, many articles reported anode studies regarding its catalytic activity. In 1999, Hibino et al. [12] reported an analysis of the exhaust gas of a Ni-GDC anode layer exposed to $\mathrm{CH}_{4} / \mathrm{O}_{2}$ flow at $950^{\circ} \mathrm{C}$ and $\mathrm{OCV}$. They demonstrated that not only hydrogen and carbon monoxide are produced by hydrocarbons oxidation but also a significant content of carbon dioxide. Dependence of catalytic activity with temperature and fuel-to-oxygen ratio was reported by Shao et al.[13,14] and by Savoie et al. [15]. Ni-SDC [13,14] and Ni-YSZ [15] anodes exhibit higher activity towards propane partial oxidation at high temperature whereas at low temperature, complete oxidation is favoured. By further lowering the temperature, anode material became fully inert to propane oxidation. Moreover, as expected, activity towards hydrocarbons partial oxidation increases for fuel-rich mixture. Gadacz et al. [16] thoroughly studied Ni-GDC activity towards propane oxidation. Catalytic behaviours of both parts of the cermet, Ni and GDC, were studied separately as a 
function of temperature and propane to oxygen ratio. GDC powder was found rather quite inactive at high temperature towards propane oxidation compared to nickel powder. Then, by studying nickel through electrical measurements and thermodynamical considerations, the authors showed that below a critical temperature value nickel is not stable and oxidises decreasing therefore its activity towards propane partial oxidation.

Carbon deposition on the anode side is also a major issue, well known through catalysis [17,18] and hydrocarbons fed SOFC [19] literature, it is usually catalysed by transition metals such as nickel. Carbon formation such as whiskers and/or capsules on the nickel particles block the active sites and reduce their catalytic activity towards hydrocarbons oxidation.

This paper presents a preliminary study on raw materials used for the cells manufacturing in order to determine the most suitable materials for the aimed application. $\mathrm{Ce}_{0.9} \mathrm{Gd}_{0.1} \mathrm{O}_{1.95}$ (GDC) was selected as electrolyte due to a high ionic conductivity at temperature corresponding to exhaust gases $\left(400-600^{\circ} \mathrm{C}\right)$. A cermet composed of nickel and GDC was used as anode component. Concerning cathode, a screening of four materials has been made, $\operatorname{La}_{0.6} \mathrm{Sr}_{0.4} \mathrm{Co}_{0.2} \mathrm{Fe}_{0.8} \mathrm{O}_{3-\delta}$ (LSCF), $\mathrm{Sm}_{0.5} \mathrm{Sr}_{0.5} \mathrm{CoO}_{3-\delta}(\mathrm{SSC})$ and $\mathrm{Ba}_{0.5} \mathrm{Sr}_{0.5} \mathrm{Co}_{0.8} \mathrm{Fe}_{0.2} \mathrm{O}_{3-\delta}$ (BSCF) [8-11] and $\mathrm{Pr}_{2} \mathrm{NiO}_{4+\delta}(\mathrm{PNO})[20,21]$.

In the present case, the gas mixture is complex and closer to real exhaust conditions than those previously studied in the literature. Activity of electrode materials in this atmosphere has never been reported so far. To determine a possible degradation of the studied materials by the gas mixture, raw cathode powders were first studied for five hours at about $600^{\circ} \mathrm{C}$, the closest temperature to exhaust gas. Cathode materials that were not degraded were then studied regarding their catalytic activity towards the studied gas mixture as a function of the temperature $\left(300-600^{\circ} \mathrm{C}\right)$. Nickel behaviour was also investigated in exhaust representative atmosphere. The evolution of the catalytic activity and chemical stability with temperature has been analysed.

\section{Experimental}

\section{Exhaust stream composition and operating temperature}

The gas mixture used in this project was based on data provided by an engine company; it has been modified to fit to laboratory conditions. The given composition corresponds to the actual stream after a catalytic converter. The exhaust stream was hence composed of hydrocarbons (HC): 1/3 propane and 2/3 propene, and oxygen but also of hydrocarbons oxidation products: hydrogen, carbon monoxide, water and carbon dioxide; nitrogen was used as balance gas. Three compositions were employed for the following analyses; their main difference lies in the oxygen concentration involving three different ratios $\mathrm{R}\left(\mathrm{HC} / \mathrm{O}_{2}\right)$ : $\mathrm{R}=0.21$ corresponding to oxygen content required for total oxidation, $\mathrm{R}=0.67$ corresponding to partial oxidation and $\mathrm{R}=0.44$, an intermediate ratio. The compositions are detailed in table 1 .

The range of temperature chosen for the following tests is comprised between 300 and $600^{\circ} \mathrm{C}$. 


\section{Raw materials}

All raw cathode materials used for tests are commercial powders. $\mathrm{Ba}_{0.5} \mathrm{Sr}_{0.5} \mathrm{Co}_{0.8} \mathrm{Fe}_{0.2} \mathrm{O}_{3-\delta}$ and $\mathrm{Pr}_{2} \mathrm{NiO}_{4+\delta}$ were supplied by MARION Technologies, $\mathrm{La}_{0.6} \mathrm{Sr}_{0.4} \mathrm{Co}_{0.2} \mathrm{Fe}_{0.8} \mathrm{O}_{3-\delta}$ and $\mathrm{Sm}_{0.5} \mathrm{Sr}_{0.5} \mathrm{CoO}_{3-\delta}$ by Fuel Cell Materials, and $\mathrm{NiO}$ by $\mathrm{Sigma}$ Aldrich. Their respective specific surface areas $\left(\mathrm{S}_{\mathrm{BET}}\right)$, measured by the Brunauer-Emmett-Teller method, are reported in table 2. BSCF, SSC and LSCF perovskites are commonly used as cathode materials for single chamber SOFCs thanks to their high mixed conductivity. Nickelates are known to be efficient cathode materials for conventional SOFCs but have never been studied yet in single chamber conditions. Therefore, PNO was selected as the fourth cathode powder.

\section{Test bed description}

All experiments were performed in a flow-through configuration (figure 1). The reactor was composed of a quartz tube inside a vertical tubular furnace; a quartz wool which supports the catalyst was placed in the middle of the tube where the diameter is narrower. Incoming gas mixture was fed to the reactor by mass flow meters controlled by computer. Water was generated by nitrogen bubbling at controlled temperature. A K-type thermocouple located nearby the catalyst is used to control the sample temperature. At the reactor outlet, the amount of water contained in the exit gas stream was determined by a humidity sensor placed downstream from the furnace; results were monitored by the Labview software. Water is then condensed and the remaining gases are quantified by an online gas chromatograph (SRA Instruments microGC3000), composed of a molecular sieve MS5A and a Pora Plot U columns. The accuracy of humidity sensor and gas chromatograph depends on the gases and the concentration range, so it is specified in table 3 for each gas.

\section{Chemical stability tests}

At first, the stability of the gas composition for the three ratios was investigated by realising reference tests without catalyst in the reactor. Then, each cathode powder was laid on the quartz wool located in the middle of the quartz tube and treated during 5 hours at $610^{\circ} \mathrm{C}$ in mixed gas flow $(60 \mathrm{~L} / \mathrm{h}) . \mathrm{X}$-ray diffraction (XRD) analyses on a Siemens D5000 using $\mathrm{Cu} \mathrm{K} \alpha$ radiation at $40 \mathrm{kV}$ and $40 \mathrm{~mA}$ were made before and after the treatment to determine whether new phases were observed in powders.

\section{Catalytic tests}


Only stable cathode materials were kept for catalytic tests which were performed from $200 \mathrm{mg}$ of powder place inside reactor from 300 to $620^{\circ} \mathrm{C}$ using a $2^{\circ} \mathrm{C} / \mathrm{min}$ ramp rate, in $60 \mathrm{~L} / \mathrm{h}$ gas flow rate. Catalytic behaviours of cathode materials were compared regarding oxygen and hydrocarbons consumption.

Normalized conversion rates of oxygen $\mathrm{X}_{\mathrm{O} 2}$ and hydrocarbons $\mathrm{X}_{\mathrm{HC}}$ by square meter of powder were used and calculated by the equation 1 :

$$
\text { Equation 1. } X_{g a s}=\frac{\left(C_{\text {in }}-C_{\text {out }}\right) \times 100}{C_{\text {in }} \times S_{B E T} \times m}
$$

Where $C_{\text {in }}$ and $C_{\text {out }}$ are the gas concentrations at the inlet and outlet respectively, $S_{\mathrm{BET}}$, the specific surface area of the powder $\left(\mathrm{m}^{2} / \mathrm{g}\right)$ and $\mathrm{m}$, the mass of the powder $(\mathrm{g})$. Conversion was normalized by square meter of powder to take into account varying surface area of studied powders.

For the anode material, only the metallic phase was studied since Gadacz et al. [16] demonstrated that GDC catalytic activity was negligible compared to nickel. Therefore, for catalytic tests, $75 \mathrm{mg}$ nickel oxide powder dispersed into $25 \mathrm{mg}$ of alumina powder were first reduced at $700^{\circ} \mathrm{C}$ for $1 \mathrm{~h} 30$ in $5 \%$ of hydrogen in nitrogen. The catalytic behaviour of the reduced powder was characterized in $60 \mathrm{~L} / \mathrm{h}$ gas flow with decreasing sample temperature from $620^{\circ} \mathrm{C}$ to $250^{\circ} \mathrm{C}$. Conversion rate $\chi$ of the hydrocarbons was calculated according to the equation 2 :

Equation 2. $\chi=\frac{\left(H C_{\text {in }}-H C_{\text {out }}\right) \times 100}{H C_{\text {in }}}$

Where $\mathrm{HC}_{\mathrm{in}}$ and $\mathrm{HC}_{\text {out }}$ are the hydrocarbons concentrations at the inlet and outlet, respectively.

XRD and Raman analyses were performed after test on nickel powders to determine whether reoxidation and/or carbon formation occurred. Raman spectra were acquired with by a Horiba Jobin Yvon XPLORA Raman spectrometer interfaced with an Olympus BX41 microscope.

\section{Results and discussion}

\section{Chemical stability}

\section{Gas mixture stability}

Isothermal reference tests were performed for the three ratios $\mathrm{R}$ at $610^{\circ} \mathrm{C}$. Before any measurements, gas composition was measured at room temperature for all $\mathrm{HC} / \mathrm{O}_{2}$ ratios by chromatography and results are reported in table 3 . This will be considered as the actual initial gas composition used in the following tests.

According to chromatographic analyses, for the $610^{\circ} \mathrm{C}$ reference tests, no modification of gas concentrations for the oxygen rich ratio $\mathrm{R}=0.21$ and the intermediate ratio $\mathrm{R}=0.44$ was noticed. Moreover, no carbon formation was detected on the quartz wool for both ratios. 
Nevertheless, for the $\mathrm{R}=0.67$ composition which contains less initial oxygen, carbon monoxide, oxygen, and hydrogen contents were measured below initial values and a simultaneous increase of carbon dioxide content was observed. These modifications imply that hydrogen and carbon monoxide oxidations forming water and carbon dioxide, respectively, occur. Moreover, at the end of test, carbon deposition was visible on the quartz wool suggesting that other reactions occur at this temperature: e.g. Boudouard equilibrium (5) or hydrocarbon cracking (6).

$$
\begin{aligned}
& 2 \mathrm{CO} \Leftrightarrow \mathrm{CO}_{2}+\mathrm{C} \\
& \mathrm{C}_{\mathrm{n}} \mathrm{H}_{\mathrm{m}} \rightarrow \mathrm{x} \mathrm{C}+\mathrm{C}_{\mathrm{n}-\mathrm{x}} \mathrm{H}_{\mathrm{m}-\mathrm{y}}+\mathrm{y} / 2 \mathrm{H}_{2}
\end{aligned}
$$

The ratio $\mathrm{R}=0.67$ was left aside while $\mathrm{R}=0.21$ and $\mathrm{R}=0.44$ were kept for the following investigations. Tests at lower temperatures have been performed and no change of the composition has been noticed for the two kept ratios.

\section{Cathode materials stability}

Cathode powders were tested with the most reducing ratio: $\mathrm{R}=0.44$. XRD results are presented on figure 2 .

Modifications of initial XRD patterns were observed for BSCF and SSC (figure 2), new phases were formed by reaction with components of the gas stream. After five hours test at $610^{\circ} \mathrm{C}$, BSCF was decomposed into $\mathrm{Sr}_{0.5} \mathrm{Ba}_{0.5} \mathrm{CO}_{3}$ and $\mathrm{SrCO}_{3}$ by reaction with $\mathrm{CO}_{2}$ from the mixture as it was already shown in previous articles [9,10]; other oxides such as CoO were formed as well. Only a few per cents of pure phase BSCF are still present at the end of the test. SSC reacted in the same way as $\mathrm{BSCF}$ forming $\mathrm{SrCO}_{3}$ by reaction with $\mathrm{CO}_{2}$ but also other oxides such as $\mathrm{Sr}_{2} \mathrm{Co}_{2} \mathrm{O}_{5}$. Only a few per cents of SSC phase were also detected after the five hours treatment. No structural change during the process was observed on LSCF powder; XRD patterns before and after test are exactly the same. Rembelski et al. observed a similar behaviour of this material in a methane/oxygen atmosphere [10]. Concerning the last cathode material, PNO, a slight degradation was seen by XRD analyses. New phases were formed: $\mathrm{Pr}_{4} \mathrm{Ni}_{3} \mathrm{O}_{10-\delta}$ and praseodymium oxides; some authors mentioned previously the formation of these phases by decomposition of PNO in air for temperatures below $850^{\circ} \mathrm{C}$ $[20,22,23]$.

BSCF and SSC cathodes were considered as unsuitable for single chamber operation in the experimental conditions studied here, due to a significant degradation caused by reaction with the gas mixture. On the contrary, LSCF was still stable even after a five hours treatment. Even though PNO was a bit degraded during the test, the main phase was still present and this cathode was kept for the next work along with LSCF.

\section{Catalytic studies}

\section{Cathode analysis}

Cathode material must be inert to hydrocarbons, carbon monoxide and hydrogen oxidations for an optimal single chamber operation. It is thus important to study the cathode materials in representative exhaust conditions to determine 
their catalytic behaviour with respect to the gas mixture. Therefore, catalytic activity of both cathode materials towards gas stream was investigated for two $\mathrm{HC} \mathrm{O}_{2}$ ratios: 0.21 and 0.44 . Blank analyses were achieved in the same conditions as catalytic tests to make sure that no modification of the gas composition occurs; the results showed that no change was noticed from 300 to $620^{\circ} \mathrm{C}$.

For LSCF, evolution of gas concentrations as a function of the temperature is presented on figure 3 for the $\mathrm{R}=0.21$ ratio. The horizontal lines symbolize the initial concentration of gases.

Gas species evolution can be divided into three domains of temperature (vertical dashed lines in figure 3).

From 300 to about $380^{\circ} \mathrm{C}$, $\mathrm{HC}$ content seems stable as well as the $\mathrm{H}_{2}$ and $\mathrm{H}_{2} \mathrm{O}$ contents. However, a lowering of $\mathrm{CO}$ and $\mathrm{O}_{2}$ values happens on this temperature range along with a simultaneous increase of $\mathrm{CO}_{2}$ concentration. So reaction (7) is the only one to occur in this zone.

$$
\mathrm{CO}+1 / 2 \mathrm{O}_{2} \rightarrow \mathrm{CO}_{2}
$$

Between 380 and $500^{\circ} \mathrm{C} \mathrm{HC}$ and $\mathrm{H}_{2}$ contents begin to diminish, $\mathrm{H}_{2} \mathrm{O}$ increases while $\mathrm{CO}$ and $\mathrm{CO}_{2}$ go on their previous trend. HC oxidations are thus occurring but are competing with $\mathrm{H}_{2}$ and $\mathrm{CO}$ oxidations (7) and (8). In this case, both partial oxidation (4) and/or complete oxidation (9) of hydrocarbons may take place.

$$
\begin{aligned}
& \mathrm{H}_{2}+1 / 2 \mathrm{O}_{2} \rightarrow \mathrm{H}_{2} \mathrm{O} \\
& \mathrm{C}_{\mathrm{n}} \mathrm{H}_{\mathrm{m}}+(\mathrm{n}+\mathrm{m} / 4) \mathrm{O}_{2} \rightarrow \mathrm{n} \mathrm{CO}_{2}+\mathrm{m} / 2 \mathrm{H}_{2} \mathrm{O}
\end{aligned}
$$

From $500^{\circ} \mathrm{C}, \mathrm{HC}$ value still decreases but a shoulder is observed on the $\mathrm{H}_{2}$ and $\mathrm{CO}$ evolutions. $\mathrm{H}_{2}$ and $\mathrm{CO}$ are thus produced while $\mathrm{HC}$ is consumed: partial oxidation (4) is occurring. Since $\mathrm{H}_{2}$ and $\mathrm{CO}$ values are still below the initial ones while $\mathrm{H}_{2} \mathrm{O}$ and $\mathrm{CO}_{2}$ contents are higher than their composition values, $\mathrm{H}_{2}$ and $\mathrm{CO}$ are consumed by (7) and (8) reactions.

For the whole temperature range, $\mathrm{O}_{2}$ is consumed by four different oxidations, thus, its evolution varies according to the oxidations taking place in the different temperature domains.

Since the catalytic behaviour for the other ratio $\mathrm{R}=0.44$ for this material is very similar to this one, it is not exposed in this paper.

Gas species evolution results for the second cathode material: PNO and R=0.21 ratio are presented on figure 4 . As previously done, three temperature domains can be highlighted (vertical dashed lines) and gas evolutions can be described in the same way. $\mathrm{O}_{2}$ consumption also varies following the oxidations occurring in the temperature range. A first zone ranging from 300 to $375^{\circ} \mathrm{C}$ is visible: $\mathrm{HC}$ and $\mathrm{H}_{2}$ contents are stable while $\mathrm{CO}$ value is modified. Only $\mathrm{CO}$ oxidation (7) is occurring in this low temperature zone.

Afterwards, from about $375^{\circ} \mathrm{C}$ to $540^{\circ} \mathrm{C}, \mathrm{HC}$ and $\mathrm{H}_{2}$ contents start to diminish. $\mathrm{CO}$ still follows the same decreasing trend as the previous zone. Hence HC oxidations (4) (9) and $\mathrm{H}_{2}$ and $\mathrm{CO}$ oxidations (7) and (8) occur. 
From $540^{\circ} \mathrm{C}, \mathrm{HC}$ content goes on lowering while a sudden change in $\mathrm{H}_{2}$ and $\mathrm{CO}$ evolutions is observed: $\mathrm{H}_{2}$ and $\mathrm{CO}$ are produced, but their content values are still below the initial ones indicating that they are probably consumed at the same time. $\mathrm{H}_{2}$ and $\mathrm{CO}$ oxidations (7) and (8) are still present but partial oxidation (4) is the main reaction in this temperature range.

The results on catalytic behaviour of PNO for $\mathrm{R}=0.44$, are illustrated on figure 5 .

For this ratio, only two zones are visible (vertical dashed lines in figure 5). Once again, $\mathrm{O}_{2}$ content varies according to the oxidations occurring in the temperature range.

At temperatures below $490^{\circ} \mathrm{C}, \mathrm{HC}$ content is stable while $\mathrm{CO}$ is consumed. $\mathrm{H}_{2}$ concentration is constant and then decreases slightly. Thus $\mathrm{CO}$ and $\mathrm{H}_{2}$ oxidations (7) and (8) are the main reactions and are thermally activated.

From $490^{\circ} \mathrm{C}, \mathrm{HC}$ value suddenly decreases while a simultaneous increase of $\mathrm{H}_{2}$ and $\mathrm{CO}$ concentrations is noticed. Therefore, HC undergo partial oxidation (4) which becomes predominant over $\mathrm{H}_{2}$ and $\mathrm{CO}$ oxidations (7) and (8) with increasing temperature.

Considering that both cathode materials catalyse the same reactions i.e. carbon monoxide, hydrogen and hydrocarbons oxidations, they were compared regarding oxygen $\mathrm{X}_{\mathrm{O} 2}$ and hydrocarbon $\mathrm{X}_{\mathrm{HC}}$ conversion rates determined by the equation 1.

As seen in the previous graphs (figures 3, 4 and 5), oxygen is consumed by four reactions: (4), (7), (8) and (9). For an optimal operation of a single cell in exhaust gas mixture; cathode material must be as inert as possible towards these oxygen consuming reactions. Both materials can thus be compared using oxygen consumption factor, its evolution with temperature is illustrated on figure 6.

LSCF and PNO materials exhibit a similar increase of oxygen consumption with temperature in both gas mixtures.

For $\mathrm{R}=0.21$, LSCF seems to consume less oxygen than PNO for temperatures lower than $600^{\circ} \mathrm{C}$, but the difference is slight. Moreover, oxygen conversion is complete near $600^{\circ} \mathrm{C}$ for both materials. At this temperature, not enough oxygen would be available for cathode operation, so it might be better to operate at temperature lower than $600^{\circ} \mathrm{C}$.

For the 0.44 ratio, $\mathrm{X}_{\mathrm{O} 2}$ follows the same trend for both materials until $550^{\circ} \mathrm{C}$, then $\mathrm{PNO}$ seems to exhibit little less oxygen consumption than LSCF, but once more the difference is not significant. In this case only LSCF cathode material presents a complete oxygen conversion.

Since both materials were hardly distinguishable regarding their catalytic activity towards oxygen consumption, hence $\mathrm{X}_{\mathrm{O} 2}$ is not well-adapted to compare them. For each ratio, both cathodes display catalytic activity towards hydrocarbons oxidation; they can thus be compared regarding their hydrocarbons conversions rate $\mathrm{X}_{\mathrm{HC}}$ (figure 7).

For $\mathrm{R}=0.21, \mathrm{X}_{\mathrm{HC}}$ rises with temperature up to $50 \%$ for $\mathrm{PNO}$ and $35 \%$ for $\mathrm{LSCF}$ around $600^{\circ} \mathrm{C}$.

For the other ratio, $\mathrm{R}=0.44, \mathrm{X}_{\mathrm{HC}}$ begins to increase from $500^{\circ} \mathrm{C}$ for $\mathrm{PNO}$ to reach $40 \%$ at the highest temperature and increases slowly until only $10 \%$ for LSCF. 
It can be noticed that for $\mathrm{R}=0.21, \mathrm{LSCF}$ and PNO have higher catalytic activity for HC oxidation than for $\mathrm{R}=0.44$. Catalytic activity towards hydrocarbons oxidation of PNO is clearly greater than LSCF especially for R=0.44.

Considering these latter catalytic results, using LSCF as cathode material in a $\mathrm{R}=0.44$ gas mixture and a temperature lower than $600^{\circ} \mathrm{C}$ would lead to best results during cell operation than with PNO.

An accurate comparison of materials catalytic activity with literature is quite difficult since some parameters differ between studies: hydrocarbons content, which is very low in this study, gas mixture composition and flow geometry. Besides, PNO has never been studied yet in single chamber configuration and no catalytic studies were thus performed in single chamber atmospheres. As for LSCF, even though conditions were not the same in the present study, HC conversion follows an equivalent trend with increasing temperature than those previously observed for tests in $\mathrm{C}_{3} \mathrm{H}_{8} / \mathrm{O}_{2}$ [8] and $\mathrm{CH}_{4} / \mathrm{O}_{2}[10]$.

\section{Anode analysis}

Unlike cathode materials, anode component must catalyse hydrocarbons partial oxidation in order to form hydrogen used in cell operation. The main issues for anode material in single chamber conditions are nickel oxidation and carbon deposition leading to anode deactivation.

Since hydrocarbons partial oxidation is an exothermic reaction, an overheating might occur as Napporn et al. observed in a methane-oxygen atmosphere [24], and loss of nickel catalytic activity could be determined by a fall of overtemperature. Nevertheless, in the gas mixture used in this work, hydrocarbons were in very small quantities $(\sim 1000$ ppm) and no such over-temperature was denoted during the experiments. So, nickel deactivation temperature was determined through evolution of the gas mixture composition and hydrocarbons conversion rate.

Nickel catalytic activity was measured for ratios $\mathrm{R}=0.21$ and $\mathrm{R}=0.44$. Evolutions of the gas concentration for the $\mathrm{R}=0.21$ ratio are described on figure 8 . As experiments have been conducting with decreasing temperatures, highest temperatures are reported on the left of the graphs and lowest on the right.

As for cathode materials, gas evolution can be split up in several temperature domains (vertical dashed lines in figure $8)$.

Between 620 and $550^{\circ} \mathrm{C}$ no clear trend is visible. $\mathrm{H}_{2}$ and $\mathrm{CO}$ contents are below initial values. $\mathrm{O}_{2}$ is consumed and stays constant at its minimum value, as well as HC content. Several reactions could take place: HC partial oxidation (4), HC complete oxidation (9), $\mathrm{CO}$ and $\mathrm{H}_{2}$ oxidations (7) and (8) and water gas shift reaction (10). In a previous study, for a propane-oxygen mixed atmosphere containing $6 \%$ of oxygen and $4 \%$ of propane, Gadacz et al. [16] determined that water gas shift equilibrium controls the gaseous composition at temperatures above $565^{\circ} \mathrm{C}$ which is in good agreement with the results exposed here. 


$$
\mathrm{CO}+\mathrm{H}_{2} \mathrm{O} \Leftrightarrow \mathrm{CO}_{2}+\mathrm{H}_{2}
$$

From $550^{\circ} \mathrm{C}$ to $450^{\circ} \mathrm{C}, \mathrm{H}_{2}$ and $\mathrm{HC}$ contents increase towards their initial composition values, they are less and less consumed. $\mathrm{CO}$ value remains almost stable and increases around $500^{\circ} \mathrm{C}$. Partial oxidation (4) and/or complete oxidation (9) might therefore compete with $\mathrm{CO}$ and $\mathrm{H}_{2}$ oxidations (7) and (8).

Then, below $450^{\circ} \mathrm{C}, \mathrm{H}_{2}$ and $\mathrm{CO}$ contents go on their previous increasing trend to reach the initial values but with a slower rate, hydrocarbons seem stable to the initial concentration. Therefore, only $\mathrm{CO}$ and $\mathrm{H}_{2}$ oxidations (7) and (8) occur below $450^{\circ} \mathrm{C}$.

As observed for cathode materials, $\mathrm{O}_{2}$ content follows the trend imposed by the oxidations occurring in each temperature domain.

Nickel catalytic activity was also studied for the $\mathrm{R}=0.44$ gas mixture and by following gas content evolution, three zones can once more be identified (vertical dashed lines in figure 9).

At the highest temperatures (from $620^{\circ} \mathrm{C}$ to $580^{\circ} \mathrm{C}$ ), $\mathrm{H}_{2}$ and $\mathrm{CO}$ values are above the initial ones, $\mathrm{HC}$ content is below the initial values and therefore is consumed. $\mathrm{O}_{2}$ is completely consumed at temperatures ranging from 620 to $600^{\circ} \mathrm{C}$. $\mathrm{HC}$ partial oxidation (4) is predominant at high temperature, but $\mathrm{CO}$ and $\mathrm{H}_{2}$ oxidations (7) and (8) prevail over $\mathrm{HC}$ oxidation (4) with decreasing temperature. HC complete oxidation (9) might also occur in addition but with a slower rate.

From $570^{\circ} \mathrm{C}$ to $450{ }^{\circ} \mathrm{C}, \mathrm{HC}$ content increases up to the initial value while $\mathrm{H}_{2}$ and $\mathrm{CO}$ concentrations decrease to a minimum and then increase again. A competition may exist between four possible reactions: HC oxidations (4), (9) and $\mathrm{CO}$ and $\mathrm{H}_{2}$ oxidations (7) and (8).

Then, below $450^{\circ} \mathrm{C}, \mathrm{HC}$ concentration is stable at initial content indicating that only $\mathrm{H}_{2}$ and $\mathrm{CO}$ oxidations (7) and (8) occur.

Once again, $\mathrm{O}_{2}$ content follows the variation corresponding to the oxidations occurring in each temperature domain.

For both ratios and temperatures above $450^{\circ} \mathrm{C}, \mathrm{HC}$ always undergo oxidations (4) and (9) but activity of nickel towards these reactions lowers progressively with decreasing temperature giving way to $\mathrm{CO}$ and $\mathrm{H}_{2}$ oxidation (7) and (8). An analysis of $\mathrm{HC}$ conversion rate $\chi$ as a function of the temperature was required to determine the temperature leading to the complete deactivation of the catalyst with respect to hydrocarbons oxidation; it was calculated according to the equation 2 and illustrated on figure 10.

No sudden loss of catalytic activity is visible; the catalyst was gradually deactivated throughout the temperature decrease. A domain of deactivation can yet be determined.

In this case, maximum $75 \%$ and $66 \%$ of $\mathrm{HC}$ conversion are obtained for $\mathrm{R}=0.44$ and $\mathrm{R}=0.21$, respectively. Nickel is therefore more active towards hydrocarbons oxidation for the $\mathrm{R}=0.44$ ratio above $600^{\circ} \mathrm{C}$. Below $600^{\circ} \mathrm{C}, \chi$ is greater for $\mathrm{R}=0.21$ than for $\mathrm{R}=0.44$. 
Deactivation of the Ni catalyst occurs gradually between 620 and $450^{\circ} \mathrm{C}$ for both ratios, and is complete below $450^{\circ} \mathrm{C}$.

Diverse phenomena could be responsible of nickel deactivation: catalyst may be completely oxidised reducing considerably its activity [16], carbon deposition may deactivate the nickel as well by polluting active sites [17], or hydrocarbons oxidation catalysis is temperature dependent and decreasing the temperature lowers the catalytic activity $[13-15]$.

In order to determine whether nickel oxidation happened during experiments, XRD analyses were carried out on samples after testing and results are given in figure 11.

After the $\mathrm{R}=0.21$ experiment, a few per cents of nickel oxide are observed, but metallic nickel is still present, however no nickel oxidation is noticed for $\mathrm{R}=0.44$.

Nickel is thus not stable and tends to oxidise into $\mathrm{NiO}$ for oxygen-rich mixtures according to reaction (11). However, even though no nickel oxide has been observed for the oxygen-lean mixture, a surface oxidation may occur which cannot be seen by XRD analyses.

$$
\mathrm{Ni}+1 / 2 \mathrm{O}_{2} \rightarrow \mathrm{NiO}
$$

The coexistence of both oxidised and reduced catalyst forms is often seen in catalytic reactor. In this case, combustion of hydrocarbons could also occur through interaction with the lattice oxygen of the NiO species $(12)[15,18]$ and so participates to HC conversion.

$$
\mathrm{C}_{\mathrm{n}} \mathrm{H}_{\mathrm{m}}+(2 \mathrm{n}+\mathrm{m} / 2) \mathrm{NiO} \rightarrow \mathrm{n} \mathrm{CO}+\mathrm{m} / 2 \mathrm{H}_{2} \mathrm{O}+(2 \mathrm{n}+\mathrm{m} / 2) \mathrm{Ni}
$$

Carbon deposition is one of the major issues for Ni catalysts. Both Boudouard and hydrocarbon decomposition reactions are not kinetically favourable but are readily catalysed by many transition metals, particularly Ni [17]. To identify whether carbon is present, Raman analyses were thereafter performed on the samples and compared to a carbon containing sample (fig. 12).

The fingerprint region of carbon species is in the wavenumber range $1200-2000 \mathrm{~cm}^{-1}$. The carbon containing sample presents two sharp peaks at about 1350 and $1600 \mathrm{~cm}^{-1}$, they are particularly visible for nickel treated in $\mathrm{R}=0.44$ gas mixture whereas only very few carbon seems present for $\mathrm{R}=0.21$.

Carbon deposition inhibit the nickel activity by blocking active sites and reduce $\mathrm{CO}$ and $\mathrm{H}_{2}$ production, this might explain the lower catalytic activity towards hydrocarbons conversion observed for $\mathrm{R}=0.44$. However a low amount of carbon was produced according to the intensity of peaks of the Raman patterns, as a result this may not be the only cause of the deactivation.

Therefore, considering these last analyses on nickel oxidation and carbon deposition, the main cause of nickel catalytic deactivation seems to be the temperature as it was already reported in the literature [13-15]. 


\section{Conclusions}

In this paper, an extended study on raw electrode materials in exhaust stream is presented in terms of stability and catalytic activity. Two ratios $\mathrm{HC}_{2} \mathrm{O}_{2}(0.21$ and 0.44$)$ were considered.

This investigation led to cathode selection among four well known materials in SOFC field. On one hand, BSCF and SSC were proven to be degraded after the five hours tests in exhaust stream and were left aside for the rest of the study. On the other hand, LSCF and PNO were stable in the selected gas mixture and exhibited similar behaviour with respect to oxygen consumption. However LSCF was less active towards hydrocarbons oxidation than PNO.

The metallic part of the anode: nickel, was also investigated regarding its catalytic activity in the gas mixture. Gradual deactivation process was underlined with decreasing temperature and the catalyst became completely inefficient below $450^{\circ} \mathrm{C}$ for both ratios. Even though carbon and nickel reoxidation were observed on the 0.44 and 0.21 samples, respectively, temperature dependence seems to be the main cause of nickel deactivation.

This study led to the determination of the optimal conditions for the cell operation. According to these results, LSCF is the most suitable cathode material due to its good stability in the selected gas mixture and its low catalytic activity towards hydrocarbons oxidation. To obtain highest performances, the cell should operate in a $\mathrm{R}=0.44$ gas mixture at temperatures lower than $600^{\circ} \mathrm{C}$ to get the best compromise between a low catalytic activity of the cathode material towards hydrocarbons oxidation and a high activity of the nickel composing the anode.

To validate these results, further work will be focused on cells preparation and their electrical performances will be evaluated in the representative exhaust gas mixture.

\section{Acknowledgements}

Funding for this project was provided by a grant from la Région Rhône-Alpes, France.

\section{References}

[1] Hibino T., Ushiki K., Sato T., Kuwahara Y. (1995) Solid State Ion. 81:1-3

[2] Kuhn M., Napporn T. (2010) Energies 3:57-134

[3] Kuhn M., Napporn T., Meunier M., Vengallatore S., Therriault D. (2009) J. Power Sources 194:941-949

[4] Herman G.S., Mardilovich P., Champion D., Beatty C., U.S. Patent US2004/0166386

[5] Uchiyama N., U.S. Patent JP2007/052388 
[6] Yano M., Hibino T., Nagao M., Okamoto K., Tomita A., Uchiyama Y., Uchiyama N. (2008) Electrochem. Solid State Lett. 11:B29-B33

[7] Nagao M., Yano M., Okamoto K., Tomita A., Uchiyama Y., Uchiyama N., Hibino T. (2008) Fuel Cells 8: 322 $-329$

[8] Shao Z., Haile S. M. (2004) Nature 431:170-173

[9] Viricelle J.-P., Udroiu S., Gadacz G., Pijolat M., Pijolat C. (2010) Fuel Cells 10:683-692

[10] Rembelski D., Viricelle J.-P., Combemale L., Rieu M. (2012) Fuel Cells 12:256-264

[11] Shao Z., Zhang C., Wang W., Su C., Zhou W., Zhu Z., Park H., Kwak C. (2011) Angew. Chem. Int. Ed. 50:1792-1797

[12] Hibino T., Wang S., Kakimoto S., Sano M. (1999) Electrochem. Solid State Lett. 2:317-319

[13] Shao Z., Haile S. M., Ahn J., Ronney P., Zhan Z., Barnett S. (2005) Nature 435:795-798

[14] Shao Z. (2004) Solid State Ion. 175:39-46

[15] Savoie S., Napporn T., Morel B., Meunier M., Roberge R. (2011) J. Power Sources 196:3713-3721

[16] Gadacz G., Udroiu S., Viricelle J.-P., Pijolat C., Pijolat M. (2010) J. Electrochem. Soc. 157:B1180-B1185

[17] Claridge J. B., Green M. L. H., Tsang S. C., York A. P. E., Ashcroft A. T., Battle P. D. (1993) Catal. Lett. 22:299-305

[18] Takenaka S., Ogihara H., Yamanaka I., Otsuka K. (2001) Appl. Catal. A 217:101-110

[19] Lo Faro M., Antonucci V., Antonucci P. L., Arico A. S. (2012) Fuel 102:554-559

[20] Ferchaud C., Grenier J.-C., Zhang-Steenwinkel Y., van Tuel M., van Berkel F., Bassat J.-M. (2011) J. Power Sources 196:1872-1879

[21] Zhou X.-D., Templeton J. W., Nie Z., Chen H., Stevenson J. W., Pederson L. R. (2012) Electrochim. Acta, 71:44-49

[22] Kovalevsky A. V., Kharton V. V., Yaremchenko A. A., Pivak Y. V., Tsipis E. V., Yakovlev S. O., Markov A. A., Naumovich E. N., Frade J. R. (2007) J. Electroceram. 18:205-218

[23] Odier P. (2000) J. Solid State Chem.153:381-385

[24] Napporn T. W., Morin F., Meunier M. (2004) Electrochem. Solid State Lett. 7:A60-A62 


\section{Figures caption}

Fig.1 Experimental set-up for powder analyses

Fig.2 XRD patterns of the four cathode materials before and after stability test. Circles correspond to the peaks of the initial structure

Fig.3 Gas content evolution as a function of temperature for the LSCF cathode and R=0.21. Represented gases: (a) HC, (b) $\mathrm{H}_{2}, \mathrm{O}_{2}$ and $\mathrm{CO}$, (c) $\mathrm{H}_{2} \mathrm{O}$, (d) $\mathrm{CO}_{2}$. Horizontal lines symbolize the initial concentrations of the gases and vertical dashed lines, the different temperature domains determined according to gas content evolutions

Fig.4 Gas content evolution as a function of temperature for the PNO cathode and R=0.21. Represented gases: (a) HC, (b) $\mathrm{H}_{2}, \mathrm{O}_{2}$ and $\mathrm{CO}$, (c) $\mathrm{H}_{2} \mathrm{O}$, (d) $\mathrm{CO}_{2}$. Horizontal lines symbolize the initial concentrations of the gases and vertical dashed lines, the different temperature domains determined according to gas content evolutions

Fig.5 Gas content evolution as a function of temperature for the PNO cathode and R=0.44. Represented gases: (a) HC, (b) $\mathrm{H}_{2}, \mathrm{O}_{2}$ and $\mathrm{CO}$, (c) $\mathrm{H}_{2} \mathrm{O}$, (d) $\mathrm{CO}_{2}$. Horizontal lines symbolize the initial concentrations of the gases. $\mathrm{O}_{2}$ initial concentration is not represented for visibility issues but lies at $0.22 \%$. Vertical dashed lines represent the different temperature domains determined according to gas content evolutions

Fig.6 $\mathrm{O}_{2}$ conversion per square meter of powder as a function of temperature for the two cathodes for ratios $\mathrm{R}=0.21$ and $\mathrm{R}=0.44$

Fig.7 HC conversion per square meter of powder as a function of temperature for the two cathodes at ratios $\mathrm{R}=0.21$ and $\mathrm{R}=0.44$

Fig.8 Gas content evolution as a function of temperature for nickel catalyst and $\mathrm{R}=0.21$. Represented gases: (a) HC, (b) $\mathrm{H}_{2}, \mathrm{O}_{2}$ and $\mathrm{CO}$, (c) $\mathrm{H}_{2} \mathrm{O}$, (d) $\mathrm{CO}_{2}$. Horizontal lines symbolize the initial concentrations of the gases and vertical dashed lines, the different temperature domains determined according to gas content evolutions 
Fig.9 Gas content evolution as a function of temperature for nickel catalyst and $\mathrm{R}=0.44$. Represented gases: (a) HC, (b) $\mathrm{H}_{2}, \mathrm{O}_{2}$ and $\mathrm{CO}$, (c) $\mathrm{H}_{2} \mathrm{O}$, (d) $\mathrm{CO}_{2}$. Horizontal lines symbolize the initial concentrations of the gases and vertical dashed lines, the different temperature domains determined according to gas content evolutions

Fig.10 HC conversion as a function of temperature for the nickel catalyst at ratios $\mathrm{R}=0.21$ and $\mathrm{R}=0.44$

Fig.11. XRD patterns of Ni-alumina mixtures after catalytic tests - triangles: alumina, circle: nickel oxide, square: nickel.

Fig.12 Raman analyses of nickel samples treated in $R=0.21$ and $R=0.44$ compared to a carbon containing sample 


\section{Tables caption}

Table 1. Experimental gas mixture.

Table 2. Powders Specific Surface Areas.

Table 3. Gas mixture composition used for materials tests. HC: $1 / 3$ propane $+2 / 3$ propene. 


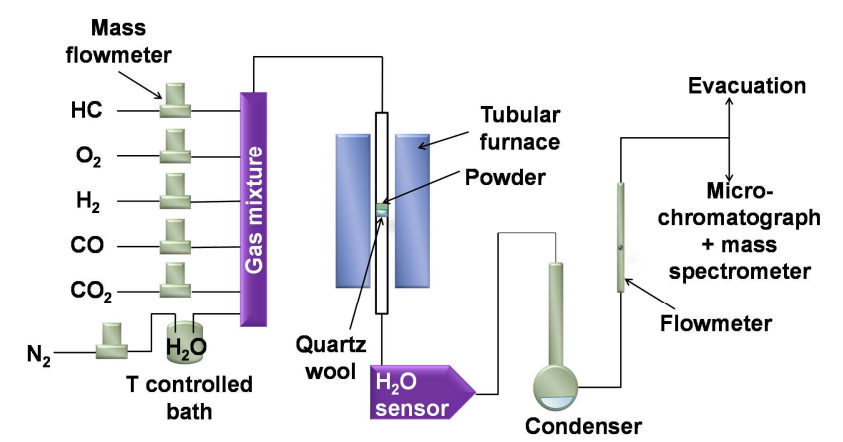

Fig.1 Experimental set-up for powder analyses
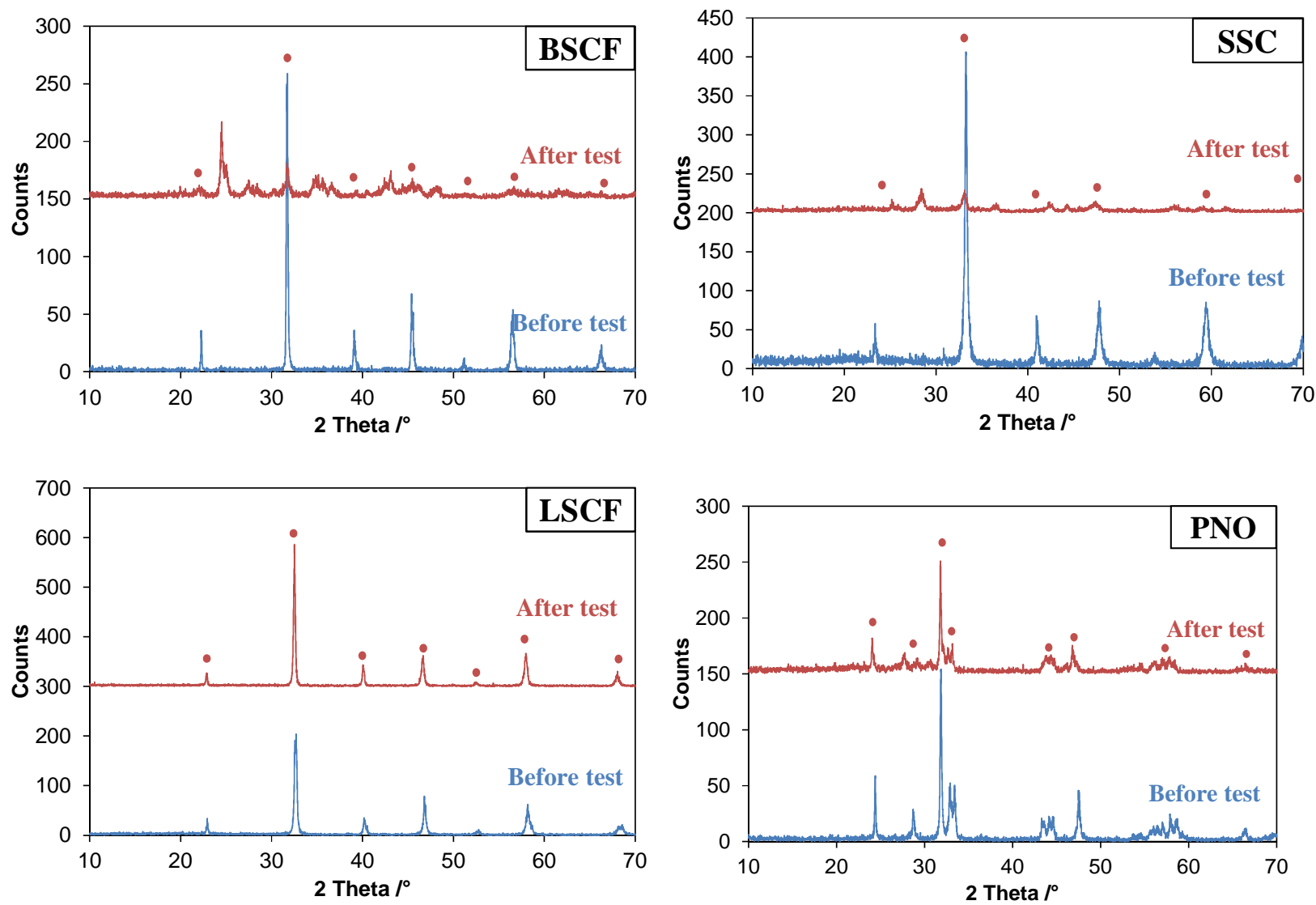

Fig.2 XRD patterns of the four cathode materials before and after stability test. Circles correspond to the peaks of the initial structure 


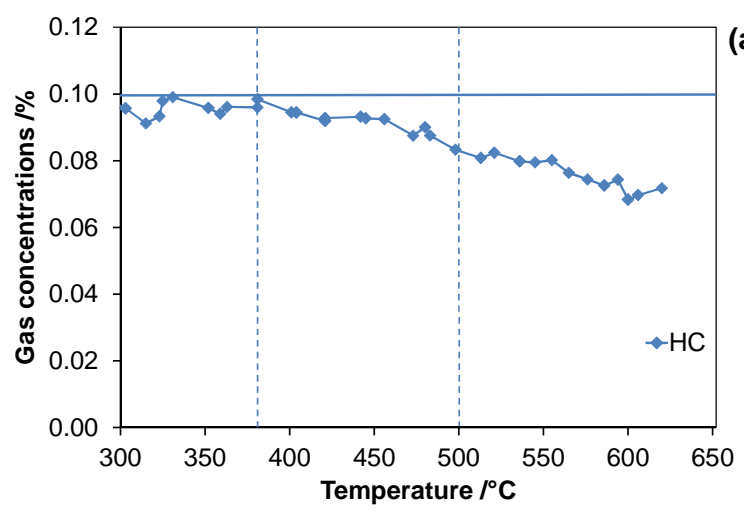

(a)
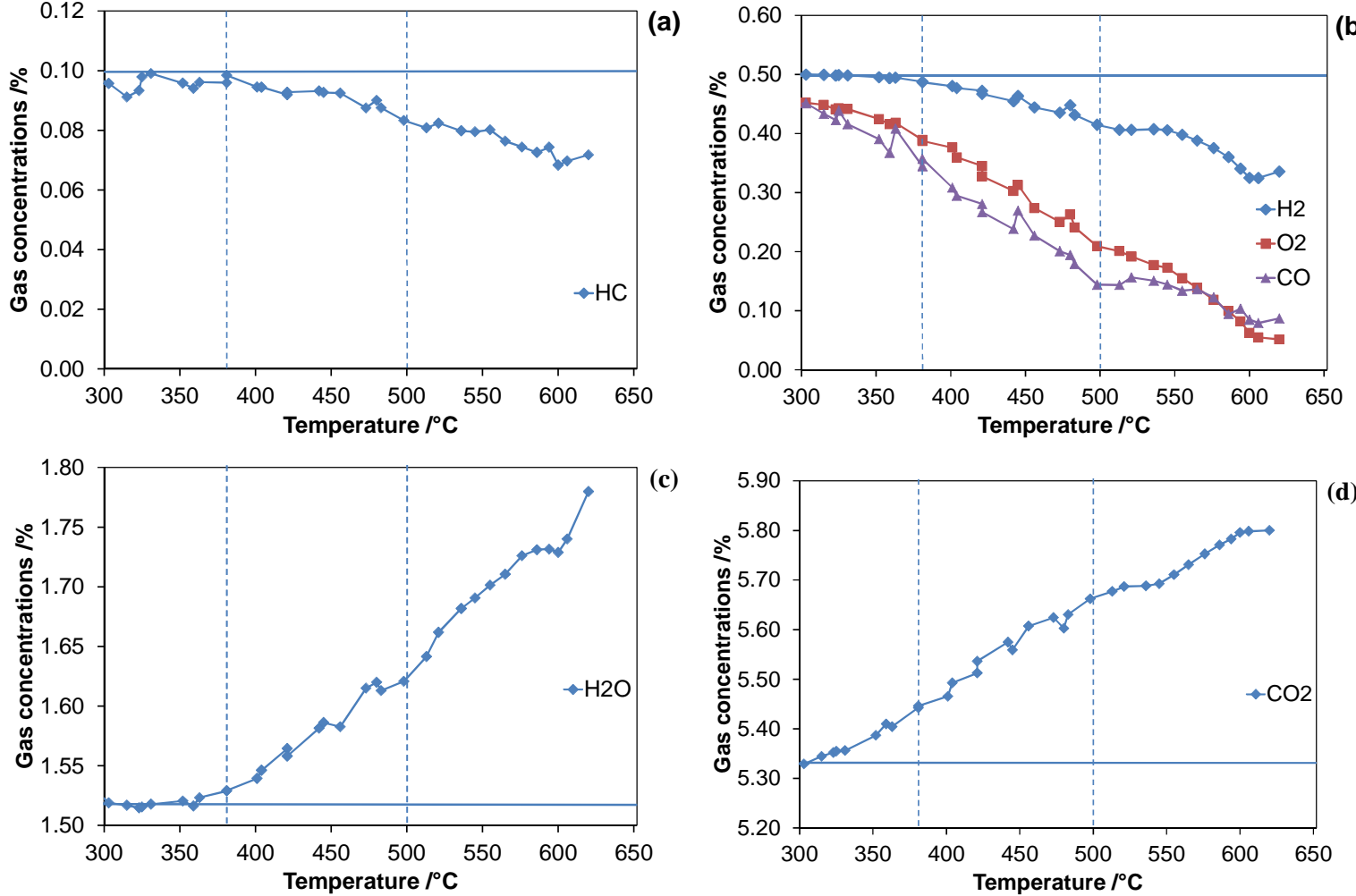

(c)

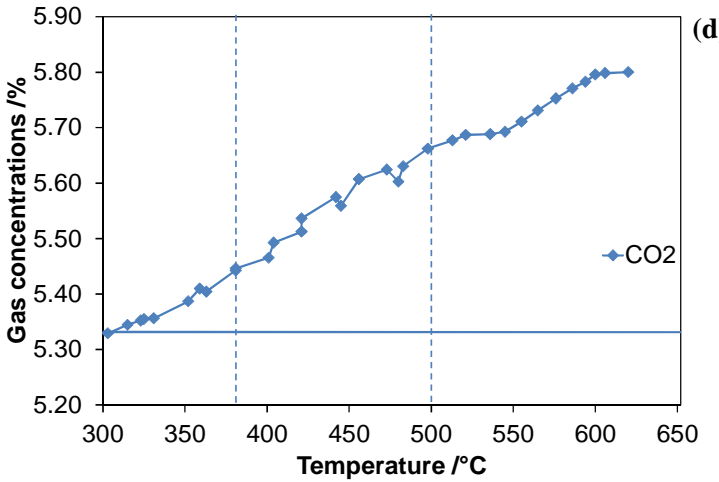

Fig.3 Gas content evolution as a function of temperature for the LSCF cathode and R=0.21. Represented gases: (a) HC, (b) $\mathrm{H}_{2}, \mathrm{O}_{2}$ and $\mathrm{CO}$, (c) $\mathrm{H}_{2} \mathrm{O}$, (d) $\mathrm{CO}_{2}$. Horizontal lines symbolize the initial concentrations of the gases and vertical dashed lines, the different temperature domains determined according to gas content evolutions
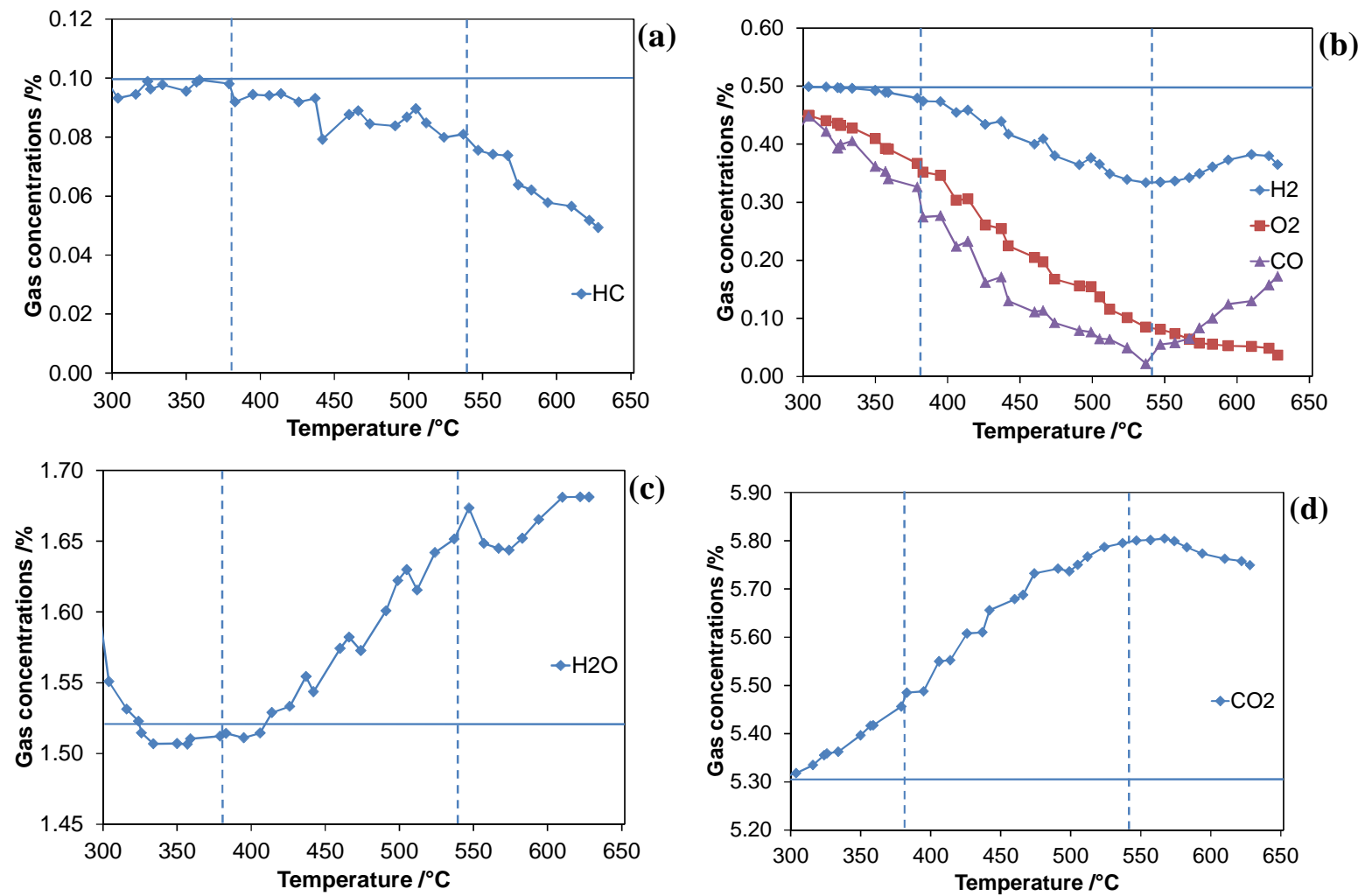

Fig.4 Gas content evolution as a function of temperature for the PNO cathode and R=0.21. Represented gases: (a) HC, (b) $\mathrm{H}_{2}, \mathrm{O}_{2}$ and $\mathrm{CO}$, (c) $\mathrm{H}_{2} \mathrm{O}$, (d) $\mathrm{CO}_{2}$. Horizontal lines symbolize the initial concentrations of the gases and vertical dashed lines, the different temperature domains determined according to gas content evolutions 

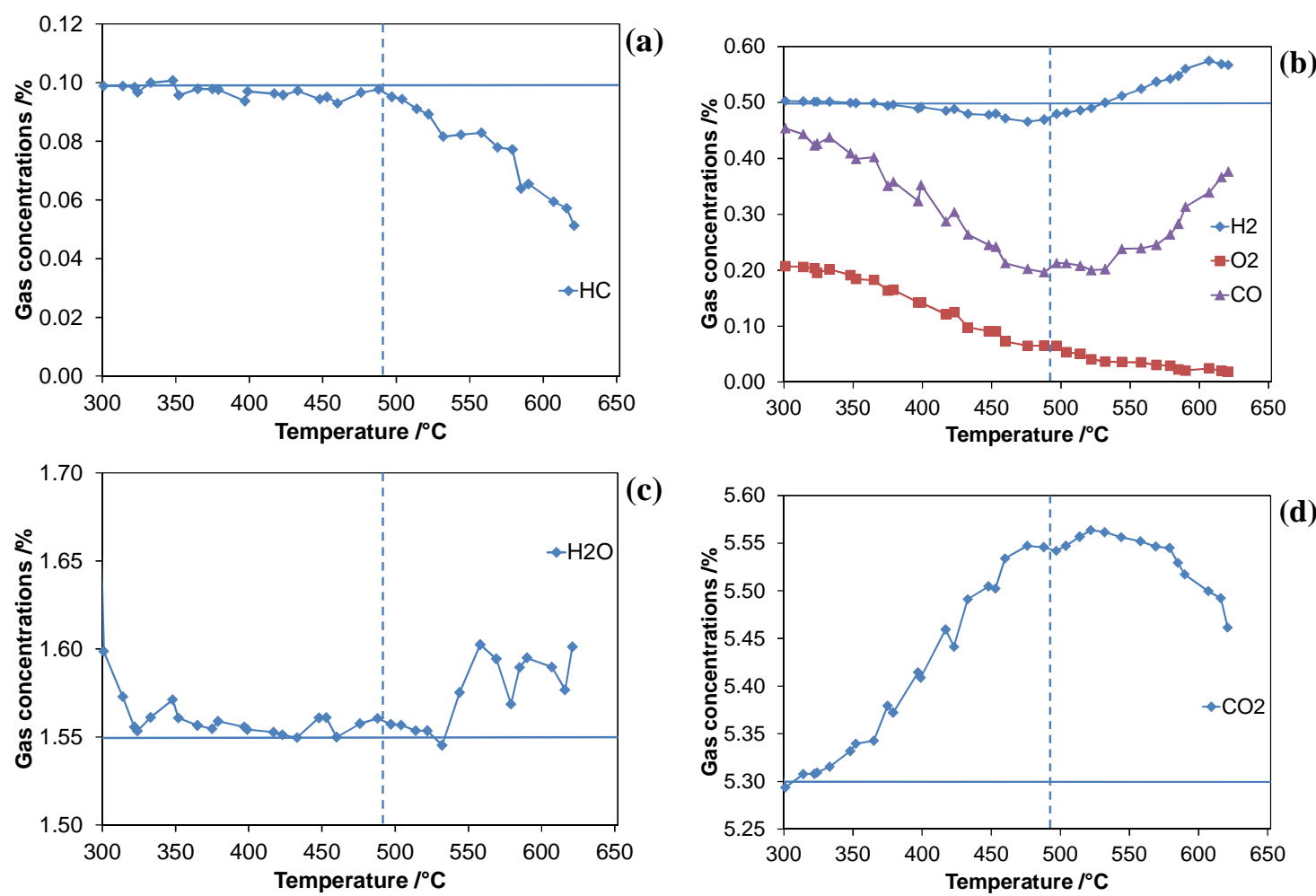

Fig.5 Gas content evolution as a function of temperature for the PNO cathode and $\mathrm{R}=0.44$. Represented gases: (a) HC, (b) $\mathrm{H}_{2}, \mathrm{O}_{2}$ and $\mathrm{CO}$, (c) $\mathrm{H}_{2} \mathrm{O}$, (d) $\mathrm{CO}_{2}$. Horizontal lines symbolize the initial concentrations of the gases. $\mathrm{O}_{2}$ initial concentration is not represented for visibility issues but lies at $0.22 \%$. Vertical dashed lines represent the different temperature domains determined according to gas content evolutions
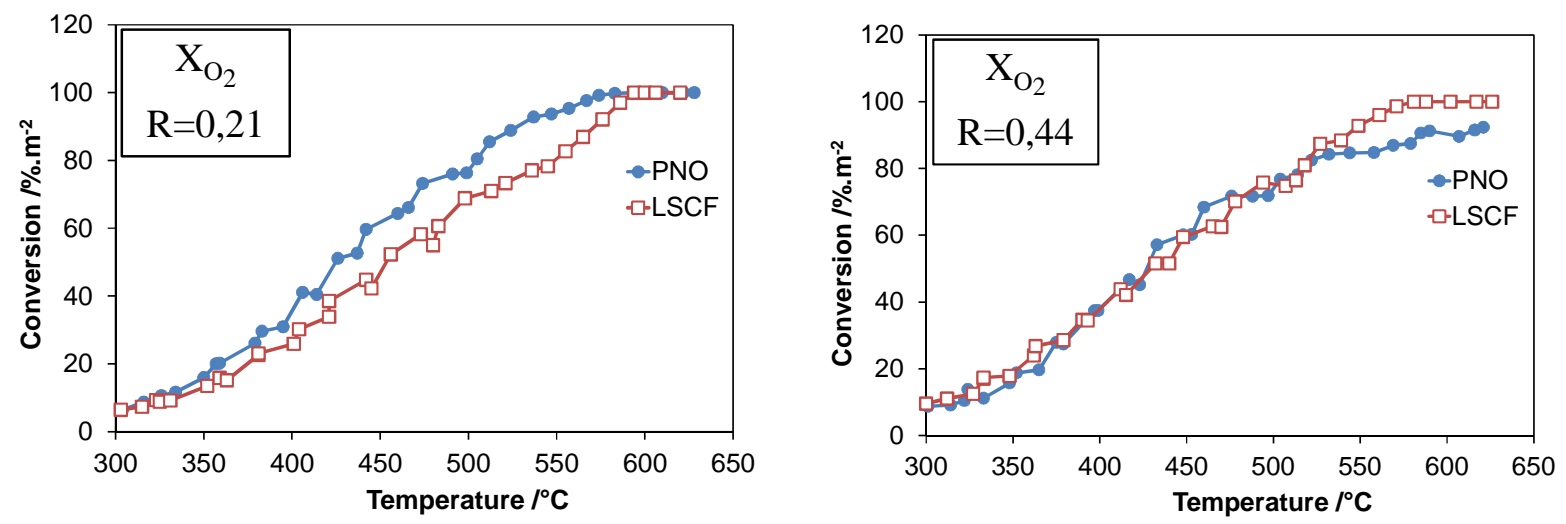

Fig.6 $\mathrm{O}_{2}$ conversion per square meter of powder as a function of temperature for the two cathodes for ratios $\mathrm{R}=0.21$ and $\mathrm{R}=0.44$ 

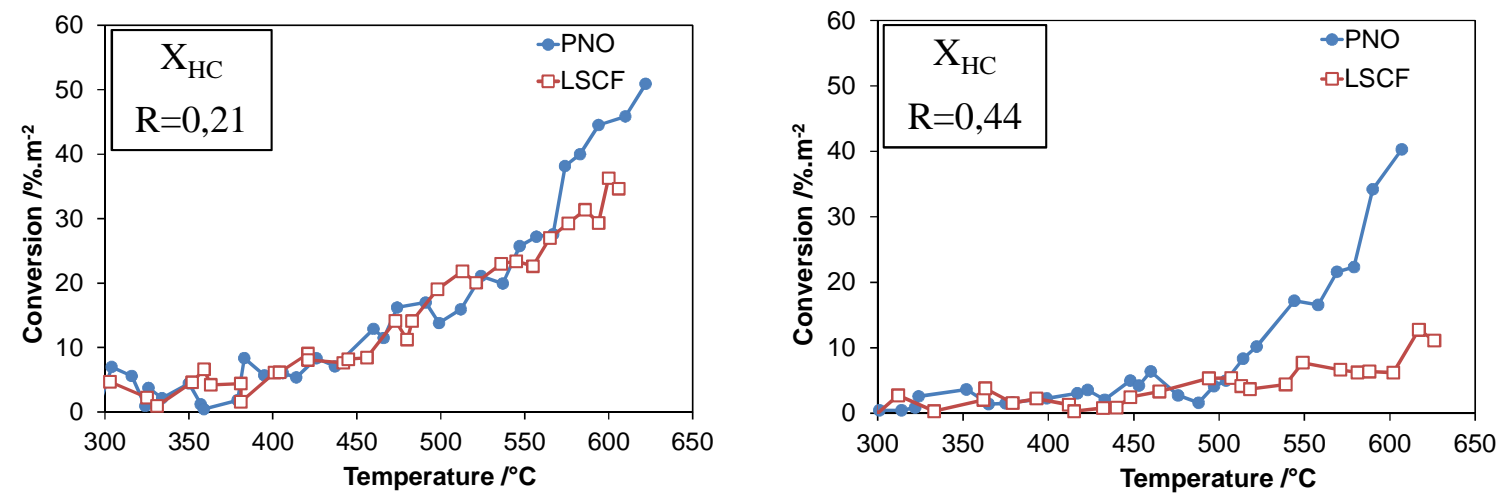

Fig.7 HC conversion per square meter of powder as a function of temperature for the two cathodes for ratios $\mathrm{R}=0.21$ and $\mathrm{R}=0.44$
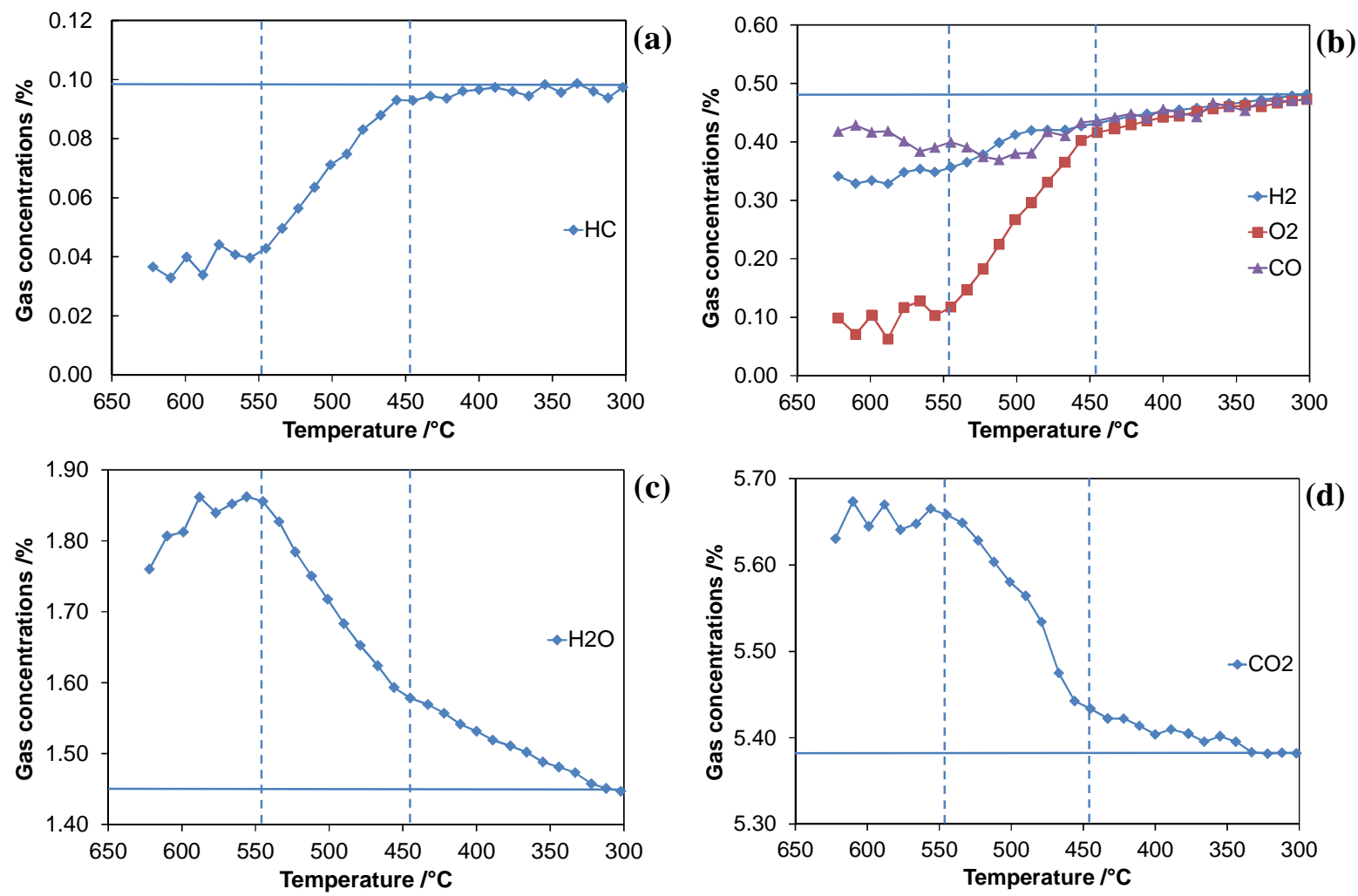

Fig.8 Gas content evolution as a function of temperature for nickel catalyst and $\mathrm{R}=0.21$. Represented gases: (a) $\mathrm{HC}$, (b) $\mathrm{H}_{2}, \mathrm{O}_{2}$ and $\mathrm{CO}$, (c) $\mathrm{H}_{2} \mathrm{O}$, (d) $\mathrm{CO}_{2}$. Horizontal lines symbolize the initial concentrations of the gases and vertical dashed lines, the different temperature domains determined according to gas content evolutions 

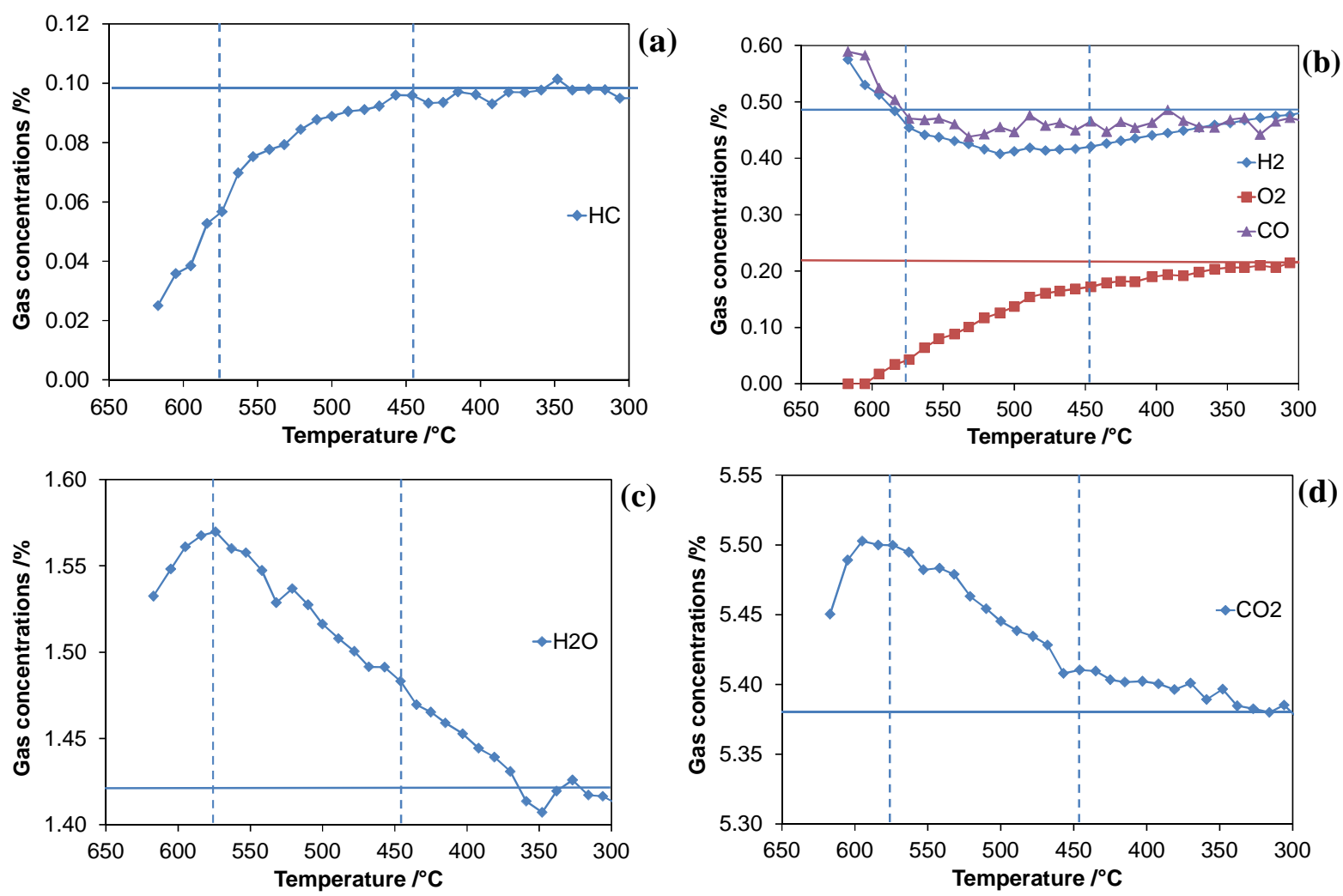

Fig.9 Gas content evolution as a function of temperature for nickel catalyst and $\mathrm{R}=0.44$. Represented gases: (a) HC, (b) $\mathrm{H}_{2}, \mathrm{O}_{2}$ and $\mathrm{CO}$, (c) $\mathrm{H}_{2} \mathrm{O}$, (d) $\mathrm{CO}_{2}$. Horizontal lines symbolize the initial concentrations of the gases and vertical dashed lines, the different temperature domains determined according to gas content evolutions

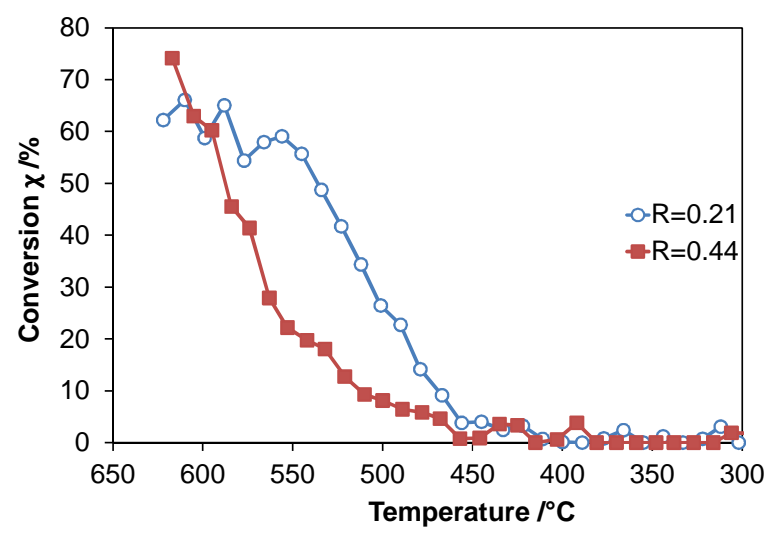

Fig.10 HC conversion as a function of temperature for the nickel catalyst at ratios $\mathrm{R}=0.21$ and $\mathrm{R}=0.44$ 


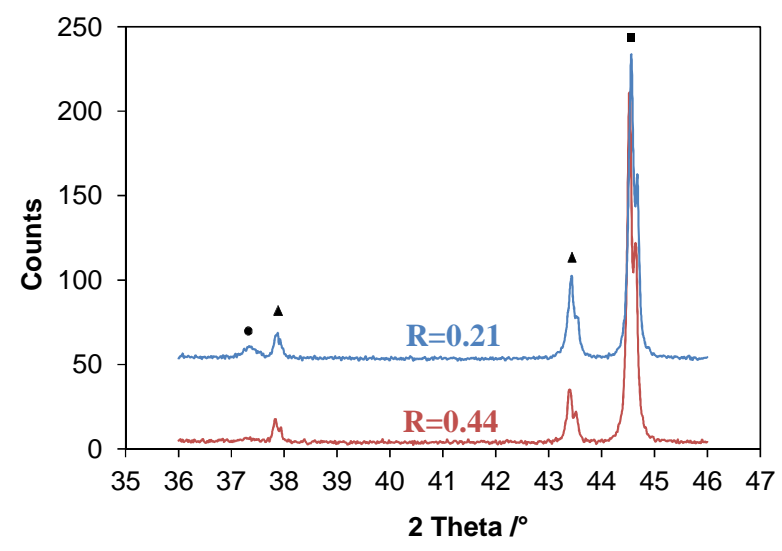

Fig.11 X-ray diffractograms of Ni-alumina mixtures after catalytic tests - triangles: alumina, circle: nickel oxide, square: nickel

Table 1 Experimental gas mixture.

\begin{tabular}{cccccccc}
\hline $\mathbf{R}=\mathrm{HC}_{\mathbf{O}}$ & $\mathbf{H C}(\mathbf{p p m})$ & $\mathbf{C O}(\%)$ & $\mathbf{H}_{2}(\%)$ & $\mathbf{O}_{2}(\%)$ & $\mathbf{C O}_{2}(\%)$ & $\mathbf{H}_{2} \mathrm{O}(\%)$ & $\mathbf{N}_{2}(\%)$ \\
\hline $\mathbf{0 . 2 1}$ & 1000 & 0.5 & 0.5 & 0.48 & 5 & 2 & 91.42 \\
$\mathbf{0 . 4 4}$ & 1000 & 0.5 & 0.5 & 0.23 & 5 & 2 & 91.67 \\
$\mathbf{0 . 6 7}$ & 1000 & 0.5 & 0.5 & 0.15 & 5 & 2 & 91.75 \\
\hline
\end{tabular}

Table 2 Powders Specific Surface Areas

\begin{tabular}{cc}
\hline Name (composition) of materials & $\mathbf{S}_{\text {BET }}\left(\mathbf{m}^{2} \mathbf{g}^{-1}\right)$ \\
\hline $\mathbf{L S C F}\left(\mathbf{L a}_{0.6} \mathbf{S r}_{0.4} \mathbf{C o}_{0.2} \mathbf{F e}_{0.8} \mathbf{O}_{3-\delta}\right)$ & 3.9 \\
$\mathbf{S S C}\left(\mathbf{S m}_{0.5} \mathbf{S r}_{0.5} \mathbf{C o O}_{3-\delta}\right)$ & 9.7 \\
$\mathbf{B S C F}\left(\mathbf{B a}_{0.5} \mathbf{S r}_{0.5} \mathbf{C o}_{0.8} \mathbf{F e}_{0.2} \mathbf{O}_{3-\delta}\right)$ & 0.85 \\
$\mathbf{P N O}\left(\mathbf{P r}_{2} \mathbf{N i O}_{4+\delta}\right)$ & 4.1 \\
$\mathbf{N i O}$ & 2.4 \\
\hline
\end{tabular}

Table 3 Gas mixture composition used for materials tests. HC: $1 / 3$ propane $+2 / 3$ propene

\begin{tabular}{cccccccc}
\hline $\mathbf{R}=\mathbf{H C} / \mathbf{O}_{\mathbf{2}}$ & $\mathbf{H C}(\mathbf{p p m})$ & $\mathbf{C O}(\boldsymbol{\%})$ & $\mathbf{H}_{\mathbf{2}}(\boldsymbol{\%})$ & $\mathbf{O}_{\mathbf{2}}(\boldsymbol{\%})$ & $\mathbf{C O}_{\mathbf{2}}(\boldsymbol{\%})$ & $\mathbf{H}_{2} \mathbf{O}(\boldsymbol{\%})$ & $\mathbf{N}_{\mathbf{2}}$ \\
\hline $\mathbf{0 . 2 1}$ & $960 \pm 30$ & $0.47 \pm 0.05$ & $0.47 \pm 0.01$ & $0.47 \pm 0.01$ & $5.35 \pm 0.05$ & $1.6 \pm 0.2$ & Complement \\
$\mathbf{0 . 4 4}$ & $960 \pm 30$ & $0.47 \pm 0.05$ & $0.47 \pm 0.01$ & $0.22 \pm 0.01$ & $5.35 \pm 0.05$ & $1.6 \pm 0.2$ & Complement \\
$\mathbf{0 . 6 7}$ & $960 \pm 30$ & $0.47 \pm 0.05$ & $0.47 \pm 0.01$ & $0.12 \pm 0.01$ & $5.35 \pm 0.05$ & $1.6 \pm 0.2$ & Complement \\
\hline
\end{tabular}

